\title{
Article \\ The Effect of Precipitation on the Microbiological Quality of Bathing Water in Areas under Anthropogenic Impact
}

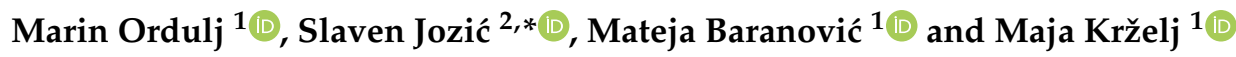 \\ 1 University Department of Marine Studies, University of Split, Ruđera Boškovića 37, 21000 Split, Croatia; \\ marin.ordulj@unist.hr (M.O.); mbaranovic@unist.hr (M.B.); maja.krzelj@unist.hr (M.K.) \\ 2 Institute of Oceanography and Fisheries, Šetalište Ivana Meštrovića 63, 21000 Split, Croatia \\ * Correspondence: sjozic@izor.hr; Tel.: +385-(0)-21-408-052
}

check for updates

Citation: Ordulj, M.; Jozić, S.; Baranović, M.; Krželj, M. The Effect of Precipitation on the

Microbiological Quality of Bathing Water in Areas under Anthropogenic Impact. Water 2022, 14, 527. https:// doi.org/10.3390/w14040527

Academic Editor: John Zhou

Received: 17 December 2021

Accepted: 7 February 2022

Published: 10 February 2022

Publisher's Note: MDPI stays neutral with regard to jurisdictional claims in published maps and institutional affiliations.

Copyright: (C) 2022 by the authors. Licensee MDPI, Basel, Switzerland. This article is an open access article distributed under the terms and conditions of the Creative Commons Attribution (CC BY) license (https:// creativecommons.org/licenses/by/ $4.0 /)$.

\begin{abstract}
Intense rainfall can affect bathing water quality, especially in areas with poorly developed sewage systems or combined sewer overflows (CSOs). The aim of this study was to assess the impact of precipitation on coastal bathing water quality in the area of Split and Kaštela (Adriatic Sea), the urban areas where CSOs were applied. The study was conducted during two bathing seasons, 2020 and 2021. The sampling of coastal waters and measurement of physical/chemical parameters was performed every two weeks and after a precipitation event of more than $2 \mathrm{~mm}$. The impact of precipitation on the quality of coastal bathing waters was not noted in the Split area nor in Kaštela, probably due to the low amount of precipitation. The quality of bathing waters in the Kaštela area was significantly worse than in the Split area, which is due to the condition of the sewage system in these areas and not the precipitation effect. It was also revealed that bathing water quality depends on the timing of sampling and the indicator against which it is assessed. Escherichia coli (E. coli) proved to be a better indicator for early morning sampling, while intestinal enterococci were better for late morning sampling.
\end{abstract}

Keywords: precipitation; bathing water quality; E. coli; intestinal enterococci; combined sewer overflows; Bathing Water Directive

\section{Introduction}

Monitoring the quality of coastal bathing waters is very important for the protection of human health and for preserving, protecting and improving the quality of the marine environment. In addition, water quality monitoring plays an important economic role in supporting economic activities such as coastal tourism, as water quality is one of the most important factors in tourists' choice of destination [1,2]. Bathing water management, including the monitoring of microbiological quality of bathing waters, is regulated in the European Union by the Bathing Water Directive (2006/7/ EC) (BWD) [3], which contains provisions for the monitoring and classification of bathing water quality, the management of bathing water quality and procedures for providing information to the public on bathing water quality. According to the BWD, bathing water quality monitoring must be carried out in accordance with the monitoring calendar, which shall be established before the beginning of each bathing season. The monitoring calendar may be suspended during 'abnormal situations' and shall be resumed as soon as possible after the end of the abnormal situation [3,4]. BWD defines abnormal situations as "an event or combination of events impacting on bathing water quality at the location concerned and not expected to occur on average more than once every four years". Croatian Regulation on sea bathing water quality [4] specifies abnormal situations as heavy rain, strong wind, large waves or the occurrence of macroalgae/phytoplankton proliferation. Some of these situations are among the main factors leading to microbiological pollution of coastal bathing waters and high levels of fecal indicator bacteria (FIB) used to assess bathing water quality. 
The main sources of fecal pollution in bathing waters are inadequately treated or untreated sewage resulting from system failures, overflows from sewage treatment or from scattered houses with improperly connected drains and poorly placed or poorly maintained septic tanks, poorly stored slurry or manure from livestock washed into streams, and animal (mostly dog) and bird droppings on beaches or crowded beaches with many bathers (https:/ / www.eea.europa.eu/airs/2018/environment-and-health/bathingwater-quality) (accessed on 12 September 2021). Pollution increases during heavy rains and floods when pollution is washed into rivers and seas. Summer rainfall and large volumes of stormwater can increase CSO outflow and discharge diluted wastewater directly into bathing waters or rivers near beaches, increasing FIB concentrations in coastal waters [5,6] (https: / /www.eea.europa.eu/airs/2018/environment-and-health/bathingwater-quality) (accessed on 12 September 2021).

Neither the Directive nor the Regulation contain instructions on how to deal with abnormal situations in terms of informing the public. Although during and after rains a significant deterioration of bathing water quality and an increased risk to bathers' health occur [7], there are no instructions on how to inform the public in such situations. The importance of informing bathers of the increased health risk of bathing during and after abnormal situations is recognized by the $\mathrm{WHO}$, which suggests that water classification may be improved by using bathing water quality prediction models to reflect the water quality to which users are actually exposed during periods not covered by 'advisory' signage, provided there is accompanying explanatory material [8]. However, during "abnormal situations', people still go into seawater without having data on the quality of the bathing water at the same time, which exposes them to significant health risks and possible infections from the water.

The studied area is rich in controlled and uncontrolled wastewater discharges that can negatively impact recreational water quality and pose a threat to human health and the environment. The main goal of this study is to examine whether precipitation affects the bathing water quality in urban and suburban areas, which are exposed to the anthropogenic impact.

\section{Materials and Methods}

\subsection{Study Area and Sampling Sites}

The study was conducted at 11 coastal sites in the coastal area of the central Adriatic Sea (Figure 1). Most of the sites are in the densely populated area of Kaštela Bay, which has a developed industrial infrastructure, marinas and popular beaches, as well as on the shores of Split, the second largest city in the Republic of Croatia and an important tourist center. Wastewater, which includes municipal wastewater (black water from toilets, grey water and industrial wastewater) and surface run-off waters (rainwater and stormwater), is collected by CSOs of the cities of Split, Kaštela and Trogir. The wastewater system of the city of Split is divided into two basins, the southern and the northern basin. While the southern basin is connected to the primary wastewater treatment plant, after which the pre-treated water is discharged into the Brač channel, the northern system has some outlets that discharge directly into the sea. The capacity of the secondary CSOs used by the cities of Kaštela and Trogir has long been exceeded. Furthermore, the secondary sewage network for the smaller parts of the cities of Kaštela and Trogir is still not fully developed or built, so sewage is still discharged directly into Kaštela Bay through many small uncontrolled discharges. A new system is currently under construction and the sewage from Trogir and Kaštela will be discharged into the Split channel. However, the storm overflow is in Kaštela Bay, which may have a negative impact on the environment. During heavy rain events, run-off water that contains litter, motor oil and gasoline washed from the urban areas is collected in the CSOs and mixed with municipal wastewater. The CSOs do not prevent the system and treatment plants from overflowing during heavy rains, which can affect the quality of recreational coastal waters. Furthermore, the relatively low polluted 
surface run-off waters can be additionally polluted by municipal wastewater and increase the negative impact on the discharge area [9].

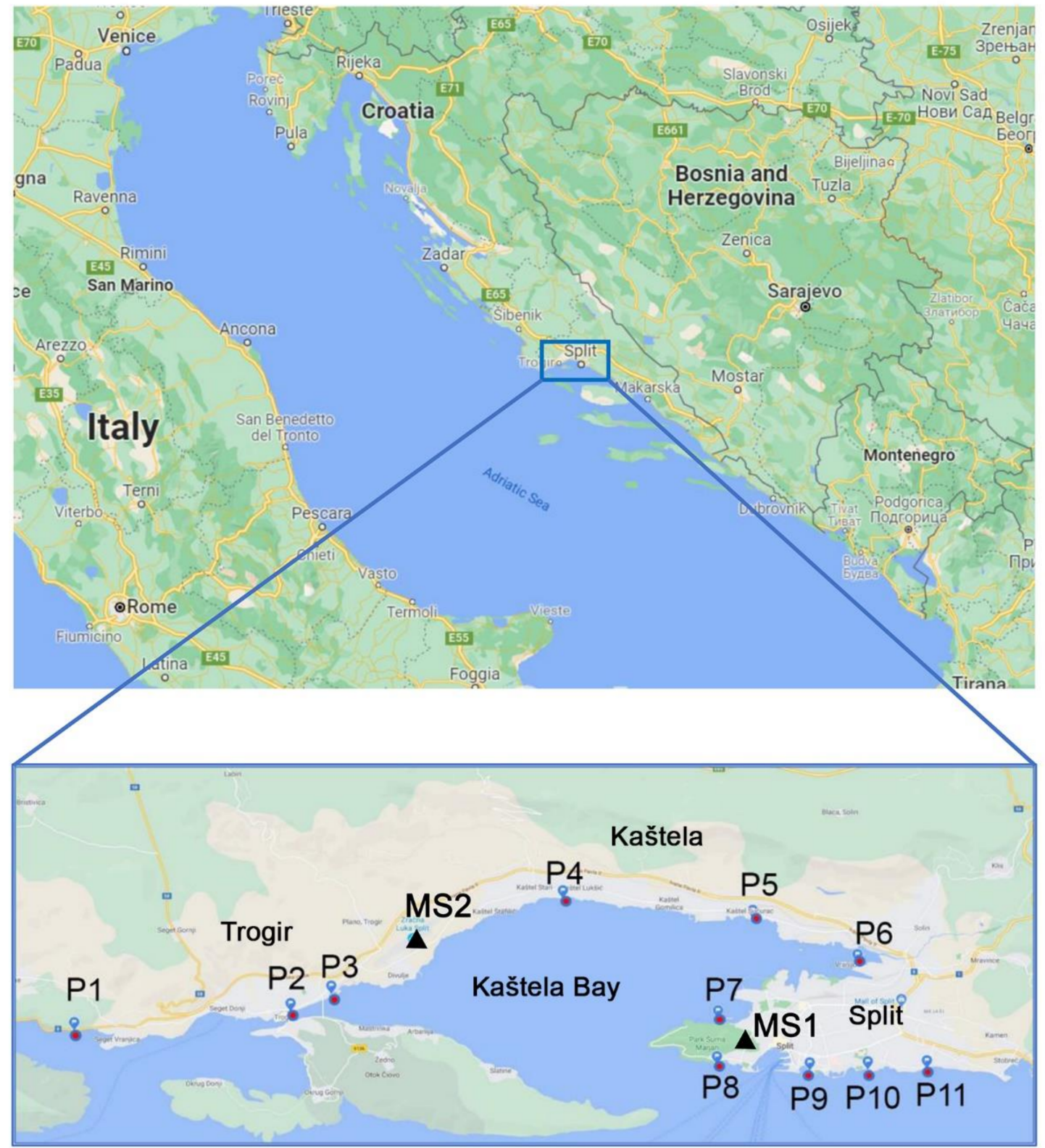

Figure 1. Study area with meteorological stations (MS1 and MS2) and sampling stations.

Most of the coastline of the monitored area is karstified (limestone), which means that precipitation quickly disappears underground. Precipitation may not have enough time to adequately purify itself and may reach the surface through the abundant coastal and submerged freshwater sources. According to historical data, the average number of rainy days during the bathing season in the study area is low, but precipitation is often short-lived and heavy, which can result in short-term pollution of coastal recreational waters through leaching.

The study area is subject to different meteorological conditions on a small scale. This means that although bathing sites are not too far away from each other, they can be affected by very different weather conditions at the same time, from local rain showers to high wind events. The selected sampling stations cover many geographically diverse areas to better determine whether precipitation levels can affect FIB concentrations in coastal waters. 
Depending on the meteorological conditions, which also correspond to the sewage systems, the stations are grouped into two areas, Split (stations P6-P11) and Kaštela (stations P2-P5).

Station P1 was selected as the reference station because it is far from settlements and faces the open sea. The station is rocky and difficult to access; therefore, the number of bathers is low during the bathing season. In addition, the area is heavily influenced by fresh water during the rainy season. The other stations are in urban areas and on popular beaches in these areas. Station P2 is located next to the parking lot in the city of Trogir, and P7 is located near the large marina in the urban area of Split. The other stations are located on popular beaches where the number of bathers is high during the bathing season. Stations P4 and P5 are in the city of Kaštela on beaches under the influence of small creeks, which can be a source of pollution. In addition, there is an uncontrolled coastal sewage outflow close to station P5. Stations in the urban area of Split are not directly affected by creeks and rivers, except for station P6, that is located in the eastern part of Kaštela Bay, near the mouth of the river Jadro. Stations P8-P11 are located next to the popular pebble beaches around the Split coastline.

\subsection{Sampling}

Sampling was conducted in two bathing seasons, from June to October 2020 and from April to October 2021. A total of 51 sampling campaigns were conducted fortnightly during the bathing seasons, as required by the Croatian Regulation on the quality of bathing water [6]. Additional sampling campaigns were conducted after a rain event of more than $2 \mathrm{~mm}$. In the case of a rain event, sampling was carried out immediately the next morning, 24 and $72 \mathrm{~h}$ after the first sampling to determine the possible influence of precipitation on the changes in the concentration of indicators of microbiological pollution. In parallel with this study, official monitoring was carried out at stations P4, P5, P9 and P11 during the period from the end of May to the end of September. Sampling was carried out by the Institute of Public Health of Split-Dalmatia County every two weeks (a total of 10 samples per bathing season). The data are available from the Institute of Oceanography and Fisheries, as one of the institutions involved in the official monitoring of coastal waters in the Republic of Croatia.

Samples were collected at the sites, from $30 \mathrm{~cm}$ depth, using sterile $500 \mathrm{~mL}$ screw-cap bottles attached to a sampling rod. Samples were stored in a portable refrigerator to avoid exposure to sunlight and processed immediately upon arrival at the laboratory.

\subsection{Microbiological Analysis}

Both indicator bacteria were determined using a membrane filtration method. For the enumeration of E. coli, the modified method ISO 9308-1:2014 was used. Chromogenic coliform agar (CCA) was incubated for $4 \mathrm{~h}$ at $36 \pm 2{ }^{\circ} \mathrm{C}$ and then $20 \mathrm{~h}$ at $44 \pm 0.5^{\circ} \mathrm{C}$ to increase selectivity without a negative impact on recovery [10]. For the enumeration of intestinal enterococci, the standard method ISO 7899-2:2000 was used [11]. The incubation on Slanetz and Bartley agar at $36{ }^{\circ} \mathrm{C} \pm 2{ }^{\circ} \mathrm{C}$ for $44 \pm 4 \mathrm{~h}$ was followed by additional incubation on prewarmed $\left(44^{\circ} \mathrm{C}\right)$ bile aesculin azide agar and incubated at $44 \pm 0.5^{\circ} \mathrm{C}$ for $2 \mathrm{~h}$.

\subsection{Physical/Chemical Analysis}

The temperature, salinity and $\mathrm{pH}$ of the seawater were measured in situ, using an YSI 1030 Pro portable probe. The probe was calibrated regularly according to the manufacturer's recommendations for $\mathrm{pH}$ and conductivity using YSI calibration solutions. Air temperature was measured using a mercury thermometer with a Celsius scale. Precipitation data recorded at two meteorological stations, MS1 and MS2 (Figure 1), were obtained from the Croatian Meteorological and Hydrological Service. 


\subsection{Data Analysis}

Examination of the data using the Kolmogorov-Smirnov test revealed that the data were not normally distributed for all parameters. Therefore, nonparametric statistics were applied. Spearman's rank order correlation was used to test statistical significance of correlation between measured parameters (E. coli, intestinal enterococci, precipitation, air temperature, water temperature, salinity and $\mathrm{pH}$ ). The Mann-Whitney U test was used to test the significance of the differences in precipitation between the Split and Kaštela areas, the values of FIB measured in periods with and without precipitation, and between the temperature and salinity measured in the study and official monitoring. The median and interquartile range (IQR) were used for descriptive presentation of the results of all measured parameters. Microsoft Excel Statistic Package (Redmond, DC, USA) and Statistica 13.1 (Stat. Soft. Inc., Tulsa, OK, USA) were used to perform the tests and present the data.

\section{Results}

\subsection{Descriptive Statistics}

The descriptive results of the parameters measured in the study, except for the precipitation results, are shown in Table 1, while the results of the parameters measured during the official monitoring are shown in Table S1. Data on physico-chemical parameters were very similar throughout the study area, while the results of FIB at stations P2, P5, and P6 differed from the results at the other stations. No statistically significant differences $(p>0.05)$ in temperature and salinity were recorded between the study and official monitoring data for any of the four overlapping stations (P4, P5, P9 and P11).

Table 1. Descriptive results (median and IQR values) of parameters measured in the study.

\begin{tabular}{cccccc}
\hline & \multicolumn{5}{c}{ Parameters } \\
\cline { 2 - 6 } Station & $\begin{array}{c}\text { Water } \\
\text { Temperature }\left({ }^{\circ} \mathbf{C}\right)\end{array}$ & Salinity & pH & $\begin{array}{c}\text { Intestinal } \\
\text { Enterococci } \\
\text { (CFU/100 mL) }\end{array}$ & E. coli (CFU/100 mL) \\
\hline P1 & $23.7(20.9-25.4)$ & $37.8(37.3-38.2)$ & $8.03(7.99-8.07)$ & $0(0.0-1.0)$ & $1(0.0-4.0)$ \\
P2 & $23.9(21.0-25.7)$ & $37.1(35.8-37.5)$ & $8.13(8.03-8.22)$ & $36(8.0-76.0)$ & $46(30.0-105.5)$ \\
P3 & $23.4(21.0-25.4)$ & $36.3(34.6-37.1)$ & $8.10(8.01-8.14)$ & $3(1.0-14.2)$ & $7(3.0-15.0)$ \\
P4 & $24.1(21.4-25.6)$ & $37.2(36.2-37.5)$ & $8.12(8.01-8.14)$ & $6(2.0-16.0)$ & $16(7.5-41.2)$ \\
P5 & $24.1(21.6-25.9)$ & $36.7(34.5-37.2)$ & $8.15(8.11-8.19)$ & $18(7.0-42.5)$ & $36(17.0-120.0)$ \\
P6 & $23.8(21.7-25.8)$ & $35.8(33.9-37.1)$ & $8.09(8.05-8.12)$ & $13(2.0-37.5)$ & $25(10.0-56.2)$ \\
P7 & $23.5(21.5-25.2)$ & $37.5(36.9-37.9)$ & $8.10(8.02-8.14)$ & $1(0.0-4.8)$ & $2(1.0-7.5)$ \\
P8 & $23.6(21.0-25.4)$ & $37.6(36.6-37.9)$ & $8.10(8.07-8.15)$ & $1(0.0-1-0)$ & $1(1.0-2-8)$ \\
P9 & $23.8(20.9-25.7)$ & $37.5(36.8-37.8)$ & $8.11(8.06-8.14)$ & $1(0.0-6.5)$ & $4(2.0-9.8)$ \\
P10 & $23.7(20.9-25.6)$ & $37.6(37.0-38.0)$ & $8.11(8.06-8.15)$ & $1(0.0-2.0)$ & $2(1.0-4.0)$ \\
P11 & $23.5(21.2-25.4)$ & $37.5(36.8-36.9)$ & $8.12(8.07-8.16)$ & $1(0.0-1.0)$ & $2(0.5 .5 .0)$ \\
\hline
\end{tabular}

Four precipitation events were recorded in the 2020 bathing season compared to ten events in 2021. The total precipitation on the days of sampling in the Kaštela area was $277.6 \mathrm{~mm}$, with the highest precipitation being $55.4 \mathrm{~mm}$ (median $15 \mathrm{~mm}$, IQR 7.6-25 mm), while in the Split area, the total precipitation was $255.3 \mathrm{~mm}$, with the highest precipitation being $54.7 \mathrm{~mm}$ (median $15.3 \mathrm{~mm}$, IQR 8.2-26.3 mm). No significant difference in precipitation was found between these two areas $(Z=0.722, p=0.470)$. Comparing precipitation by year, the amount in 2021 was significantly higher, $236.3 \mathrm{~mm}$ in Kaštela and $220.2 \mathrm{~mm}$ in Split, than in 2020, where it was 41.3 and $35.1 \mathrm{~mm}$, respectively. Precipitation on the sampling days was lower than the total precipitation (Figure 2), especially for the Kaštela area. 


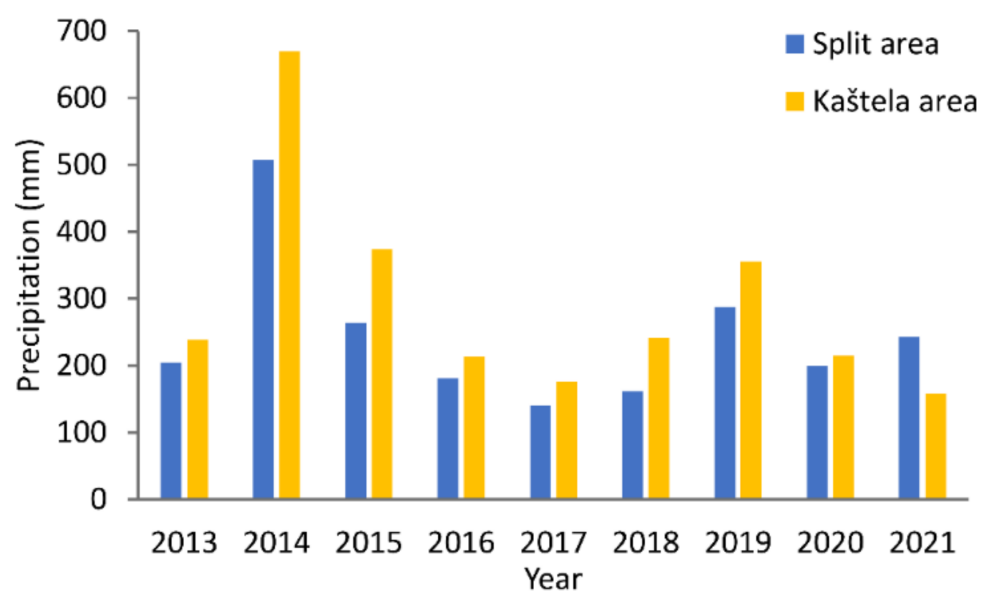

Figure 2. Total precipitation in the bathing season in the period 2013-2021.

When the data from both bathing seasons were examined, no significant correlation was found between precipitation and FIB values recorded a day after the rain (Table 2). When the data for two bathing seasons were considered separately, a statistically significant but very weak correlation $\left(\mathrm{r}_{\mathrm{s}}=0.1248, p<0.05\right)$ was found between precipitation and $E$. coli values for the 2021 bathing season (Tables S2 and S3).

Table 2. Spearman's correlation coefficients between the examined variables for both bathing seasons. Statistically significant correlations $(p<0.05)$ are underlined.

\begin{tabular}{cccc}
\hline Parameters & $\boldsymbol{E}$. coli & Intestinal Enterococci & Precipitation \\
\hline Air temperature & -0.074408 & $\underline{-0.097515}$ & 0.035217 \\
Water temperature & 0.012499 & $\underline{-0.226446}$ & $\underline{0.116098}$ \\
Salinity & $-\underline{0.269378}$ & $\underline{0.080992}$ & -0.035646 \\
pH & -0.012774 & $\underline{0.688259}$ & $\underline{0.141659}$ \\
E. coli & 1.000000 & 1.000000 & 0.070780 \\
Intestinal enterococci & $\underline{0.688259}$ & 0.055395 & 0.055395 \\
Precipitation & 0.070780 & & 1.000000 \\
\hline
\end{tabular}

When considering the data for only one area, a statistically significant but very weak correlation was found between precipitation and the two indicator bacteria values for the Split area $\left(\mathrm{r}_{\mathrm{s}}=0.112\right.$ for E. coli; $\mathrm{r}_{\mathrm{s}}=0.143$ for intestinal enterococci, $\left.p<0.05\right)$, while no significant correlation was found between these parameters for the Kaštela area (Tables 3 and 4).

Table 3. Spearman correlation coefficients between the examined variables for both bathing seasons for Split area. Statistically significant correlations $(p<0.05)$ are underlined.

\begin{tabular}{|c|c|c|c|}
\hline Parameters & E. coli & Intestinal Enterococci & Precipitation \\
\hline Air temperature & 0.021580 & -0.046341 & -0.105498 \\
\hline Water temperature & $\underline{0.134070}$ & $\underline{0.113334}$ & 0.035564 \\
\hline Salinity & -0.099866 & $\overline{-0.024540}$ & -0.015196 \\
\hline $\mathrm{pH}$ & -0.256724 & -0.084286 & $\underline{0.143502}$ \\
\hline E. coli & 1.000000 & $\underline{0.503115}$ & $\underline{0.111749}$ \\
\hline Intestinal enterococci & $\underline{0.503115}$ & $\overline{1.000000}$ & $\overline{0.143276}$ \\
\hline Precipitation & $\overline{0.111749}$ & $\underline{0.143276}$ & $\overline{1.000000}$ \\
\hline
\end{tabular}

When the data were considered separately for only one area and one season, a statistically significant but very weak correlation $\left(r_{s}=0.162, p<0.05\right)$ was found only between precipitation and intestinal enterococci in the Split area and only for the 2021 bathing season (Tables S4-S7). 
Table 4. Spearman correlation coefficients between the examined variables for both bathing seasons for the Kaštela area. Statistically significant correlations $(p<0.05)$ are underlined.

\begin{tabular}{cccc}
\hline Parameters & E. coli & Intestinal Enterococci & Precipitation \\
\hline Air temperature & -0.111462 & -0.112434 & -0.132546 \\
Water temperature & -0.117736 & -0.067930 & -0.024022 \\
Salinity & $\underline{-0.337801}$ & $\underline{-0.292302}$ & -0.087983 \\
pH & $\underline{0.183863}$ & $\underline{0.228400}$ & $\underline{0.143986}$ \\
E. coli & $\underline{1.000000}$ & $\underline{0.753913}$ & 0.083236 \\
Intestinal enterococci & $\underline{0.753913}$ & 0.000000 & 0.025341 \\
Precipitation & 0.083236 & & 1.000000 \\
\hline
\end{tabular}

Considering only the FIB data recorded during rainy periods, no significant correlation was found between precipitation and FIB values either for the day after the rain or for 24 and $72 \mathrm{~h}$ after the first sampling event (Tables S8-S10).

To determine the effect of precipitation on FIB values, we tested the differences between FIB values recorded during precipitation periods and periods without precipitation for each control point separately. No statistically significant difference $(p>0.05)$ was found in FIB values for any of the control points.

\subsection{Bathing Water Quality}

The data on microbiological quality of bathing water were processed in accordance with guidelines set out in the BWD [3] and national regulations [6]. Bathing water quality categories were determined using the 90th and 95th percentiles of the FIB data and using national criteria (Table 5), since Croatian criteria for E. coli are considerably stricter than those recommended by the BWD. Due to the large differences in the values, the data obtained were log transformed to better represent them in a common graph. The water quality of each water sample was assessed using national criteria (Table 6), as BWD does not specify such criteria.

Table 5. Croatian standards for assessment of bathing water quality at the end of bathing season and for three preceding bathing seasons.

\begin{tabular}{|c|c|c|c|c|}
\hline Parameters & Excellent & Good & Sufficient & Poor \\
\hline Intestinal enterococci (CFU /100 mL) & $\leq 100 *$ & $\leq 200 *$ & $\leq 185^{* *}$ & $>200 * *$ \\
\hline E. $\operatorname{coli}(\mathrm{CFU} / 100 \mathrm{~mL})$ & $\leq 150 *$ & $\leq 300 *$ & $\leq 300 * *$ & $>300 * *$ \\
\hline
\end{tabular}

Table 6. Croatian standards for assessment of bathing water quality after each analysis.

\begin{tabular}{cccc}
\hline Parameters & Excellent & Good & Sufficient \\
\hline Intestinal enterococci $(\mathrm{CFU} / 100 \mathrm{~mL})$ & $\leq 60$ & $61-100$ & $101-200$ \\
E. coli $(\mathrm{CFU} 100 / \mathrm{mL})$ & $\leq 100$ & $101-200$ & $201-300$ \\
\hline
\end{tabular}

Significant differences in water quality were found in the study area. FIB values, expressed in colony forming Units (CFU) as the 90th and 95th percentiles, differed by up to three orders of magnitude among the control points-3-1413 CFU/100 mL for E. coli and 3-695 CFU /100 mL for intestinal enterococci (Figure 3). A similar spatial pattern of FIB values was also found when both seasons were observed separately (Figures S1a,b and S2a,b). 


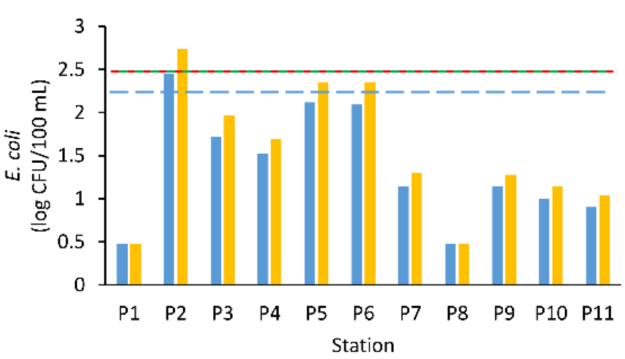

(a)

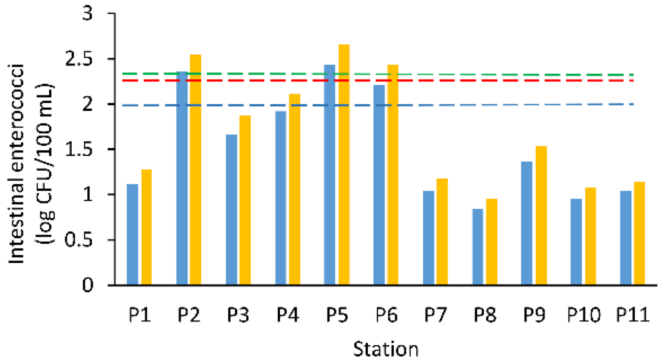

(b)

Figure 3. Bathing water quality categories based on the 90th (blue columns) and 95th (orange columns) percentiles of all E. coli (a) and intestinal enterococci (b) values for both bathing seasons. Dashed lines present water quality thresholds (blue-excellent; green-good; red-sufficient).

Based on two years of monitoring data, two bathing areas were assessed as poor (P2 and P5), one as good (P6) and the other as excellent. Based on official monitoring data for the same period, of the four stations included in this study, three have excellent water quality (P4, P9 and P11) and one has good water quality (P5). Considering the results of both indicator bacteria after each sampling, water quality exceedances (poor water quality) were found in 29 (4.8\%) out of a total of 605 samples (Figure 4). Of the total number of exceedances, 11 were based on the values of both indicators, 5 were based only on the values of E. coli, and 11 were based only on intestinal enterococci. In 56 (80\%) of the 70 cases where there were differences in bathing water quality categories when only one indicator bacteria was used for assessment, the quality was worse when assessed by the number of intestinal enterococci (Figure 5). As many as 24 (34\%) of the changes in water quality were from excellent to poor or satisfactory, and all were due to increased concentrations of intestinal enterococci.

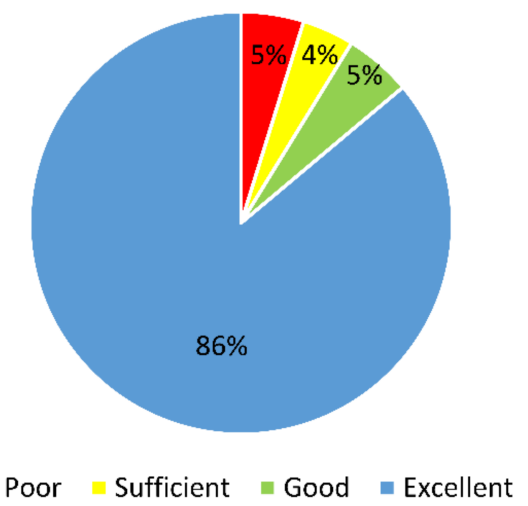

Figure 4. The percentage of bathing water quality categories for 2020 and 2021 bathing season.

\begin{tabular}{|r|l|l|l|l|l|l|l|l|l|l|} 
Number of samples & $\mathbf{6}$ & $\mathbf{1 8}$ & $\mathbf{2 3}$ & $\mathbf{5}$ & $\mathbf{3}$ & $\mathbf{1}$ & $\mathbf{3}$ & $\mathbf{2}$ & $\mathbf{2}$ & $\mathbf{7}$ \\
\hline $\begin{array}{r}\text { Water quality based on } \mathrm{E} \text {. coli } \\
\text { Water quality based on IE }\end{array}$ & & & & & & & & & & \\
\hline
\end{tabular}

Figure 5. Water samples with different quality (blue-excellent, green-good, yellow-sufficient, redpoor) when assessed with only one indicator bacteria, E. coli and intestinal enterococci (IE) separately. The numbers indicate the number of samples.

\section{Discussion}

We analyzed concentrations of fecal indicator bacteria and abiotic parameters at 11 stations in densely populated areas where coastal waters are heavily used for recreational purposes. Although precipitation in the studied area during the study period did not deviate considerably from the averages of the previous period and no summer showers were recorded, showers have occurred with increasing irregularity in many nearby areas 
during the past decade, and the frequency of such events is predicted to increase and the affected area to expand [12,13].

From the results of the present study, it can be concluded either that precipitation in the studied area had no effect on FIB concentration in bathing water or that the precipitation was not sufficient to cause a higher FIB input because the lower precipitation that carry FIBs was probably quickly absorbed by the karstic terrain before reaching the bathing waters [14]. The latter is supported by the fact that there was no significant difference in temperature and salinity between the present study and the official monitoring, and the $\mathrm{pH}$ values were very similar to those previously reported for the studied area [15]. Sampson et al. [16] also attributed the lack of correlation between below average precipitation and FIB to the short time it takes for surface water to reach the beach, as the samples were taken within $24 \mathrm{~h}$ of measurable rainfall. In addition, Park et al. [17] found a very limited effect of $16 \mathrm{~mm}$ precipitation on microbiological water quality, although they found a higher density of fecal coliform bacteria at low precipitation, which could be caused by high tides.

However, many studies showed a significant effect of precipitation on FIB values. The authors suggest that rain does not necessarily lead to increased concentrations of indicator bacteria, and many factors have an influence on the possible relationship, such as the amount of rain, the time that elapses from rain to sampling, the tides and wind direction [18-20]. The amount and diffusion characteristics of the fecal material discharged certainly play an important role. Considering the relatively dry summers in the studied area during the present study, the possible influence of precipitation on the increase in the FIB values could be studied out of season, in spring or autumn, when precipitation is higher. Intense autumn rains after a long dry period are likely to increase the FIB load in coastal areas [21], and so this will probably also be the case in the studied area. Notwithstanding the fact that environmental conditions are not the same as during the bathing season, additional studies conducted out of season would certainly provide better insight into the impact of precipitation on bathing water quality.

The difference in water quality between the two studied areas is noticeable. Almost $8 \%$ of all water samples taken in the Kaštela area were of poor quality, which is very similar to the results (5\%) found in previous study that covered official bathing sites in the Kaštela area [22]. In the Split area, $2 \%$ of the water samples were of poor quality, and $70 \%$ of these were at station P6. The high FIB values recorded in the eastern and western parts of Kaštela Bay during non-precipitation periods indicate that these parts of the bay are still exposed to short-term fecal pollution from sources other than freshwater springs and sewage overflows after rainy periods. Station P5 is one of the most polluted coastal bathing sites in Croatia and one of the few sites classified as poor in the overall classification (4 years) in 2021. The most likely reason for the worse water quality in the study than in official monitoring is the more frequent sampling and the larger number of samples per site (55 versus 20 ), which increase the probability of detecting short-term pollution at polluted sites. The importance of the number of samples in water quality assessment was recognized by Leecaster and Weisberg [23], who found that with the minimum number of four samples per site per season as set by BWD, there is only a low $(5 \%)$ chance of detecting single-day exceedances, even at the most polluted sites. According to the WHO [8], this leads to significant misclassification of bathing water sites. Croatia is among the EU countries with the most sampling campaigns per site per season (10), but it seems that more sampling at sites exposed to pollution would be necessary to detect short-term pollution events more successfully.

Of all the water samples that were not of excellent quality, $83 \%$ differed in quality category when each sample was assessed with only one indicator bacteria. Since most of samples were classified in the lower quality category based on the number of intestinal enterococci, this group of bacteria seems to be more indicative of fecal pollution in coastal bathing waters than E. coli. Džal et al. [22] found a very similar percentage of differently classified samples $(75 \%)$, but in contrast to the results of the present study, most of the exceedances (51\%) were due to $E$. coli levels and only $10 \%$ were due to intestinal enterococci 
levels. These differences could be explained in part by different sampling times. The average sampling time at which exceedances were recorded in the present study was 11:15 a.m., in contrast to the Džal et al. [22] study, where it was 9:20 a.m. The later the sampling, the higher the intensity of solar radiation, so the indicator bacteria in the seawater are more exposed to its negative effects. It is well-known that solar radiation is the most important environmental factor in reducing allochthonous bacteria in the marine environment, and that $E$. coli is generally less resistant than intestinal enterococci [24-27]. In the morning, when the load of fecal material is greatest and solar radiation is weakest, the number of E. coli is higher because their share in fresh fecal material is greater than that of intestinal enterococci. Therefore, the exceedances at this time were mainly caused by increased levels of E. coli. Over time, solar radiation increases and reduces $E$. coli much more rapidly than intestinal enterococci. The ratio between the number of $E$. coli and enterococci in seawater changes, so that enterococci become relatively more numerous and become the main cause of water quality exceedances.

\section{Conclusions}

Although recognized in many studies as a major source of fecal pollution in coastal waters, precipitation was not associated with the indicators of fecal pollution of bathing waters, E. coli and intestinal enterococci, in the present study. This could be because precipitation in the area has no effect on the input of fecal material or because the amount of precipitation was not sufficient to cause higher fecal pollution in the area. Further research is needed to obtain a better picture of the above problems in this area.

The results of the microbiological quality of bathing waters in the studied area indicate that the Kaštela area is still polluted by small uncontrolled wastewater discharges and that the water quality in bathing areas near identified wastewater discharges should be monitored more frequently to detect short-term pollution. Furthermore, the results show the importance of monitoring both indicator organisms, E. coli and intestinal enterococci, as the exceedances in this study were mainly caused by high levels of intestinal enterococci due to later sampling, in contrast to previous studies conducted in the same area where most of the exceedances were due to high levels of E. coli.

Supplementary Materials: The following are available online at https://www.mdpi.com/article/10 $.3390 / w 14040527 /$ s1, Figure S1: Bathing water quality categories based on the 90th (blue columns) and 95th (red columns) percentiles of all E. coli (a) and intestinal enterococci (b) values for the 2020 bathing season, Figure S2: Bathing water quality categories based on the 90th (blue columns) and 95th (red columns) percentiles of all E. coli (a) and intestinal enterococci (b) values for the 2021 bathing season. Table S1: Descriptive results (median and IQR values) of parameters measured in the official monitoring, Table S2: Spearman correlation coefficients between the examined variables for the 2020 bathing season, Table S3: Spearman correlation coefficients between the examined variables for the 2021 bathing season, Table S4: Spearman correlation coefficients between the examined variables in the Split area for the 2020 bathing season, Table S5: Spearman correlation coefficients between the examined variables in the Split area for the 2021 bathing season, Table S6: Spearman correlation coefficients between the examined variables in the Kaštela area for the 2020 bathing season, Table S7: Spearman correlation coefficients between the examined variables in the Kaštela area for the 2021 bathing season, Table S8: Spearman correlation coefficients between the examined variables measured one day after the rainfall, Table S9: Spearman correlation coefficients between the examined variables measured $24 \mathrm{~h}$ after the first sampling, Table S10: Spearman correlation coefficients between the examined variables measured $72 \mathrm{~h}$ after the first sampling.

Author Contributions: Conceptualization, M.O. and S.J.; methodology, M.O. and M.B.; validation, M.O. and M.K.; formal analysis, M.O. and S.J.; investigation, M.O., M.K. and M.B.; resources, M.O. and M.K.; data curation, M.O., S.J. and M.K.; writing—original draft preparation, S.J. and M.O.; writing-review and editing, S.J., M.O. and M.K; visualization, M.O. and S.J.; supervision, M.O., S.J. and M.K.; project administration, M.K. and M.O.; funding acquisition, M.K. and M.O. All authors have read and agreed to the published version of the manuscript. 
Funding: This study was funded by the European Regional Development Fund under the Interreg Italy-Croatia CBC Programme as part of the WATERCARE project (Water management solutions for reducing microbial environment impact in coastal areas, project ID 10044130).

Institutional Review Board Statement: Not applicable.

Informed Consent Statement: Not applicable.

Data Availability Statement: The dataset presented in this study is available on request from the corresponding author. The data are not publicly available because they are stored in the Cloud of the Interreg WATERCARE project.

Acknowledgments: We thank Božena Tokić for her participation in sampling and analysis during the first year of project implementation. We also thank our colleagues from the Teaching Institute of Public Health of Split-Dalmatia County, who carried out the official monitoring in the studied area.

Conflicts of Interest: The authors declare no conflict of interest. The funders had no role in the design of the study; in the collection, analyses, or interpretation of data; in the writing of the manuscript, or in the decision to publish the results.

\section{References}

1. Preißler, S. Evaluation of the quality of European coastal water by German tourists. Coast. Chang. S. Balt. Sea Reg. Coastline Rep. 2009, 12, 177-186.

2. Dodds, R.; Holmes, M.R. Education and certification for beach management: Is there a difference between residents versus visitors? Ocean Coast. Manag. 2018, 160, 124-132. [CrossRef]

3. The European Parliament and the Council of the European Union. Directive 2006/7/EC of 15 February 2006 Concerning the Management of Bathing Water Quality and Repealing Directive 76/160/EEC; European Union: Brussels, Belgium, 2006.

4. Official Gazette of the Republic of Croatia" Narodne Novine" 73/2008. Regulation on Sea Bathing Water Quality; The Government of The Republic of Croatia: Zagreb, Croatia, 2008.

5. Al Aukidy, M.; Verlicchi, P. Contributions of combined sewer overflows and treated effluents to the bacterial load released into a coastal area. Sci. Total Environ. 2017, 607-608, 483-496. [CrossRef] [PubMed]

6. Penna, P.; Baldrighi, E.; Betti, M.; Bolognini, L.; Campanelli, A.; Capellacci, S.; Casabianca, S.; Ferrarin, C.; Giuliani, G.; Grilli, F.; et al. Water quality integrated system: A strategic approach to improve bathing water management. J. Environ. Manag. 2021, 295, 113099. [CrossRef] [PubMed]

7. Wyer, M.D.; Kay, D.; Jackson, G.F.; Dawson, H.M.; Yeo, T.L. Indicator organism sources and coastal water quality: A catchment study on the island of Jersey. J. Appl. Bacteriol. 1995, 78, 290-296. [CrossRef] [PubMed]

8. World Health Organization (WHO). WHO Recommendations on Scientific, Analytical and Epidemiological Developments Relevant to the Parameters for Bathing Water Quality in the Bathing Water Directive (2006/7/EC). 2018. Available online: https:/ / circabc.europa.eu/d/d/workspace/SpacesStore/9e89152c-7cfe-4391-9bcf-c173519e8181/WHO\%20 Recommendations\%20on\%20EC\%20BWD.pdf (accessed on 16 December 2021).

9. Vander Tuig, K.; Hufnagel, C.; Carrier, A.; Christian, D.; Struck, S. The great sewer separation debate. Proc. Water Environ. Fed. Water Environ. Fed. 2009, 18, 254-271. [CrossRef]

10. Jozić, S.; Vukić Lušić, D.; Ordulj, M.; Frlan, E.; Cenov, A.; Diković, S.; Kauzlarić, V.; Fiorido Đurković, L.; Stilinović Totić, J.; Ivšinović, D.; et al. Performance characteristics of the temperature-modified ISO 9308-1 method for the enumeration of Escherichia coli in marine and inland bathing waters. Mar. Pollut. Bull. 2018, 135, 150-158. [CrossRef] [PubMed]

11. ISO 7899-2. Water Quality—Detection and Enumeration of Intestinal Enterococci_Part 2: Membrane Filtration Method; International Organization for Standardization: Geneva, Switzerland, 2000.

12. Botturi, A.; Gozde Ozbayram, E.; Tondera, K.; Gilbert, N.I.; Rouault, P.; Caradot, N.; Gutierrez, O.; Daneshgar, S.; Frison, N.; Akyol, C.; et al. Combined sewer overflows: A critical review on best practice and innovative solutions to mitigate impacts on envi-ronment and human health. Crit. Rev. Environ. Sci. Technol. 2021, 51, 1585-1618. [CrossRef]

13. Ferrarin, C.; Penna, P.; Penna, A.; Spada, V.; Ricci, F.; Bilić, J.; Krželj, M.; Ordulj, M.; Šikoronja, M.; Đuračić, I.; et al. Modelling the Quality of Bathing Waters in the Adriatic Sea. Water 2021, 13, 1525. [CrossRef]

14. Vukić Lušić, D.; Kranjčević, L.; Maćešić, S.; Lušić, D.; Jozić, S.; Linšak, Ž.; Bilajac, L.; Grbčić, L.; Bilajac, N. Temporal variations analyses and predictive modeling of microbiological seawater quality. Water Res. 2017, 119, 160-170. [CrossRef] [PubMed]

15. Kwokal, Z.; Francisković-Bilinski, S.; Bilinski, H.; Branica, M. A comparison of anthropogenic mercury pollution in Kastela Bay (Croatia) with pristine estuaries in Ore (Sweden) and Krka (Croatia). Mar. Pollut. Bull. 2002, 44, 1152-1157. [CrossRef]

16. Sampson, R.W.; Swiatnicki, S.A.; McDermott, C.M.; Kleinheinz, G.T. The Effects of rainfall on Escherichia coli and total coliform levels at 15 Lake Superior recreational beaches. Water Resour. Manag. 2006, 20, 151-159. [CrossRef]

17. Park, K.; Jo, M.R.; Kim, Y.K.; Lee, H.J.; Kwon, J.Y.; Son, K.T.; Lee, T.S. Evaluation of the effects of the inland pollution sources after rainfall events on the bacteriological water quality in Narodo area, Korea. Korean J. Fish. Aquat. Sci. 2012, 45, 414-422. [CrossRef] 
18. Ackerman, D.; Weisberg, S.B. Relationship between rainfall and beach bacterial concentrations on Santa Monica bay beaches. J. Water Health 2003, 1, 85-89. [CrossRef]

19. Kleinheinz, G.T.; McDermott, C.M.; Hughes, S.; Brown, A. Effects of rainfall on E. coli concentrations at Door County, Wisconsin beaches. Int. J. Microbiol. 2009, 2009, 876050. [CrossRef] [PubMed]

20. Zhang, W.; Wang, J.; Fan, J.; Gao, D.; Ju, H. Effects of rainfall on microbial water quality on Qingdao No. 1 Bathing Beach, China. Mar. Pollut. Bull. 2013, 66, 185-190. [CrossRef]

21. Economy, L.M.; Wiegner, T.N.; Strauch, A.M.; Awaya, J.D.; Gerken, T. Rainfall and streamflow effects on estuarine Staphylococcus aureus and fecal indicator bacteria concentrations. J. Environ. Qual. 2019, 48, 1711-1721. [CrossRef]

22. Džal, D.; Kosović, I.N.; Mastelić, T.; Ivanković, D.; Puljak, T.; Jozić, S. Modelling bathing water quality using official monitoring data. Water 2021, 13, 3005. [CrossRef]

23. Leecaster, M.K.; Weisberg, S.B. Effect of sampling frequency on shoreline microbiology assessments. Mar. Pollut. Bull. 2001, 42, 1150-1154. [CrossRef]

24. Fujioka, R.S.; Hashimoto, H.H.; Siwak, E.B.; Young, R.H. Effect of sunlight on survival of indicator bacteria in seawater Appl. Environ. Microbiol. 1981, 41, 690-696. [CrossRef] [PubMed]

25. Davies-Colley, R.J.; Bell, R.G.; Donnison, A.M. Sunlight inactivation of enterococci and fecal coliforms in sewage effluent diluted in Seawater. Appl. Environ. Microbiol. 1994, 60, 2049-2058. [CrossRef] [PubMed]

26. Sinton, L.W.; Davies-Colley, R.J.; Bell, R.G. Inactivation of enterococci and faecal coliforms from sewage and meatworks effluentsin seawater chambers. Appl. Environ. Microbiol. 1994, 60, 2040-2048. [CrossRef] [PubMed]

27. Jozić, S.; Morović, M.; Šolić, M.; Krstulović, N.; Ordulj, M. Effect of solar radiation, temperature and salinity on the survival of two different strains of Escherichia coli. Fresenius Environ. Bull. 2014, 23, 1852-1859. 